\title{
Surgical Outcome of Endoscopic Transsphenoidal Surgery in Prolactinoma
}

\author{
MOHAMED EMARA, M.D. and RAMY TEAMA, M.D. \\ The Department of Neurosurgery, Faculty of Medicine, Banha University, Egypt
}

\begin{abstract}
Background: Prolactinoma represent approximately $30 \%$ of pituitary adenomas, they are the most common type of functioning pituitary adenoma, few studies have recently reexamined efficacy of transsphenoidal surgery in prolactinoma.

Aim of Study: The aim of this work is to evaluate the outcome of patients with prolactinoma treated by transsphenoidal surgery, to identify the factors that affect the surgical outcome leading to remissions or recurrence.

Patients and Methods: This is a retrospective study of 27 patients with prolactinoma treated in Neurosurgery Department in Benha University in the period between January 2015 and January 2018 of which 21 were women and 6 were men, the mean age was $40( \pm) 15$ years.
\end{abstract}

Results: Post-operative remission was obtained in $70 \%$ of cases. Better outcome was associated with smaller preoperative tumor size, amount of removed tumor intraoperatively, lack of invasion of nearby structures and lack of suprasellar extension. The mean follow-up period was 36 months. Recurrence was observed in $20 \%$ of cases during this period ( 5 cases). In patients with pre-operative dopamine agonist resistance treated again after surgery there was significant reduction of prolactin level in about half of cases.

Conclusion: Gross total removal, smaller tumor size, lack of cavernous sinus invasion and lack of suprasellar extension is associated with better outcome. Dopamine agonist resistant cases show better response to dopamine agonist after debulking.

Key Words: Prolactinoma - Dopamine agonist - Prolactine - Transsphenoidal surgery.

\section{Introduction}

THE transsphenoidal approach for resection of a pituitary adenoma was first performed by Herman Schloffer more than 100 years ago. Subsequently, the transsphenoidal approach created great interest, and a variety of modifications of this approach were described shortly thereafter. As discussed in

Correspondence to: Dr. Mohamed Emara, The Department of Neurosurgery, Faculty of Medicine,

Banha University, Egypt a report by Henderson, Harvey Cushing was the first to present a large clinical series of 231 transsphenoidal pituitary adenoma resections in 1939. Later he abandoned the procedure in favor of transcranial approachesd due to lack of adequate pre-operative imaging [4]. Two reasons make transsphenoidal technique resurfaced. First, the development of imaging techniques such as CT and MR imaging provided accurate information about the size and location of a lesion and allowed for appropriate patient selection and determination of the appropriate surgical access. Second, the introduction of the operating microscope and later endoscopy greatly improved intraoperative illumination and visualization $[13,15,19]$. There is a paucity of literature reporting the endocrinological outcome following use of a purely endoscopic transsphenoidal technique $[\mathbf{1 1 , 1 6}$. Here we present our experience in 27 cases of prolactinoma treated surgicall by endoscopic approach in our center.

\section{Patients and Methods}

\section{Patient demographic data:}

We analyzed a retrospectively collected database of 27 patients who underwent endoscopic endonasal surgery for prolactinoma between January 2015 and January 2018 in Neurosurgery Department at Benha University Hospital. Functional tumors were resected using a purely endoscopic endonasal transsphenoidal approach. For each operation, the duration of surgery, estimated blood loss, relevant laboratory values, adjuvant treatments, and complications were recorded.

\section{Pre-operative evaluation:}

The pre-operative evaluation consisted of a detailed interview, a general medical examination, and endocrinologic, neurologic, ophthalmologic, and neuroradiologic evaluations. Prolactin levels 
were determined by radioimmunoassay (normal values, 6 to $25 \mathrm{ng} / \mathrm{ml})$.

Prior to resection, all patients underwent contrast enhanced MR imaging. Tumor invasion of the CS was defined. Routinely, the surgical site was analyzed by CT brain or contrast-enhanced MR imaging on post-operative day 1, 3 months after surgery, and then at yearly intervals.

\section{Surgical Technique:}

Prior to surgery, all patients received antibiotics and glucocorticoids. We use neuronavigation for some of our cases. We used a 4-mm rigid endoscope (Karl Storz) and an intraoperative MR imaging neuronavigation system (Medtronic). Briefly, which side of the nasal cavity to use was determined by the nasal anatomy (septal deviation and megaturbinate), lateral extension, and size of the tumor. A unilateral approach was used in most cases, except for large tumors. The entire procedure was performed with a hand-held, short $0^{\circ}$ endoscope $(4 \mathrm{~mm}$, $18 \mathrm{~cm}$ ). The superior and middle turbinates were identified and gently pushed aside laterally. Mucosa from the sphenoidal ostium to the choana at the base of the vomer was coagulated and thereafter opened up, pushing away the vomer until the contralateral ostium appeared. A large sphenoidotomy was performed, and the bone of the sella turcica was removed from one cavernous sinus to the other and from the anterior skull base to the clivus.

Adenomas were removed using a piecemeal technique similar to that applied in microscopic surgery. At the end of the procedure, the sellar and suprasellar regions were explored using $0^{\circ}, 30^{\circ}$ endoscopes pushed up through the sella turcica. At the end of the procedure, jugular compression was applied to detect any CSF fistula before closing. We closed cases using autologous fat and a piece of bone, nasal packs were used in case of CSF leake. Lumbar drain was used in some cases.

\section{Endocrinological evaluation:}

All patients underwent pre-and post-operative endocrinological evaluation for free cortisol, $\mathrm{ACTH}$, free thyroxine, thyroid-stimulating hormone, PRL, GH, IGF-I, testosterone, estradiol, luteinizing hormone, and folliclestimulating hormone to assess for endocrinological derangements (except for 2 patient, who was lost to endocrinological follow-up). The diagnosis of a prolactinoma was made based on serum PRL levels of $>150 \mathrm{ng} / \mathrm{ml}$ in combination with typical clinical symptoms. endocrinological remission was defined as postoperative PRL levels of $<25 \mathrm{ng} / \mathrm{ml}$.

\section{Results}

In this series, 27 patients with PRL-secreting adenomas underwent an endoscopic transsphenoidal tumor resection. The mean age of this group was 40 years (range 26-55 years), and it was composed of 21 female and 6 male patients.

The majority of cases seek medical attention due to manifestations of hyperprolactinemia. The rest of patients with larger tumor diameter present with severe headache $(11 \%)$ and acute severe diminution of vision $(22 \%)$. There was positive relation between larger tumor diameter and these manfestations $(p<0.002)$. In patients with loss of vision visual field testing revealed bitemporal defects in 4 cases and hemianopia in two cases.

Patients with apoplexy presented with severe acute diminution of vision in 4 cases and severe headache in 2 cases. Cavernous sinus invasion was present in 4 cases $(14,8 \%)$, suprasellar extension was present in 10 cases (37\%). In this series 3 cases were operated before (11\%). Hypogonadism was present in 2 cases, hypothyroidism in 1 case and panhypothyroidism in 1 case.

Most of these patients (67\%) received medical therapy to control hyperprolactinemia. Medical therapy failed for 3 main reasons: (1) Insufficient control of excess hormone secretion (15 patients);

(2) Enlargement of the pituitary adenoma despite maximum medical therapy (3 patients); and (3) intolerable adverse side effects ( 9 patients).

Nine patients with PRL secreting adenomas underwent resection without a trial of medical therapy. Six of patients presented with acute severe diminution of vision, and 3 presented with severe headaches, of which apoplexy was the cause in 6 patients.

Analysis of pre-operative imaging revealed an average maximum diameter of $1.9 \mathrm{~cm}$ (range 0.8 $4.5 \mathrm{~cm}$ ). Thus, $70.5 \%$ of prolactinomas were considered as macroadenomas.

\section{Post-operative remission:}

There was a positive relation between postoperative remission and GTR, small tumor size, lack of suprasellar extension, lack of CS invasion $(p<0.05)$.

In patients with pre-operative dopamine agonist resistance treated again after surgery there was significant reduction of prolactin level in about half of cases. 


\section{Post-operative complications:}

There was no operative or perioperative death in this study. Three patients developed post operative CSF leaks, two of them were recovered on bed rest and medical treatment and one was treated

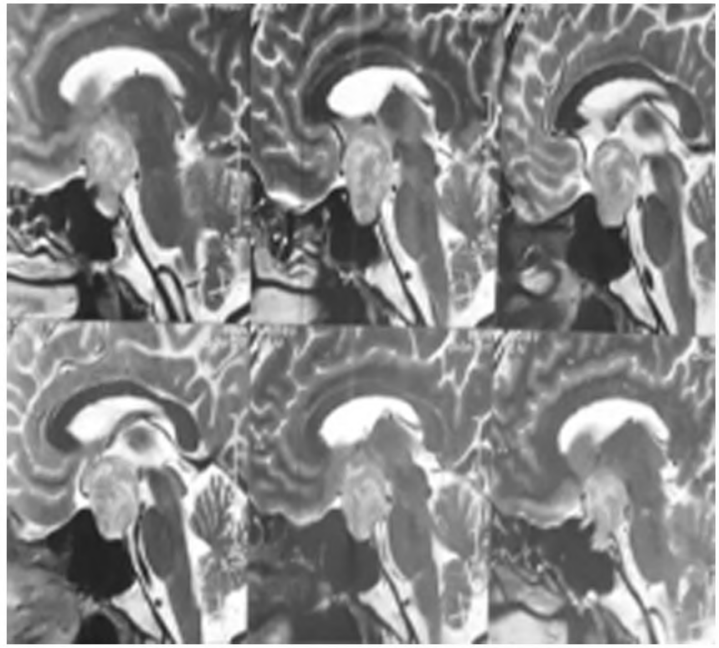

(A)

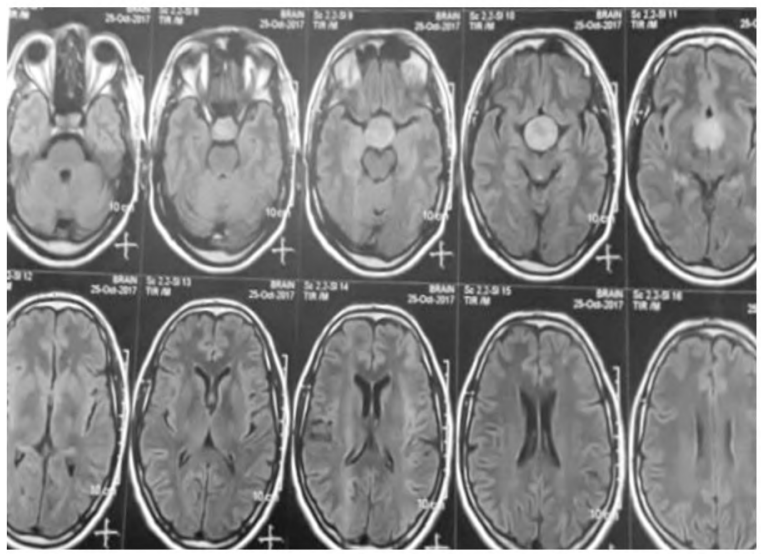

(C)

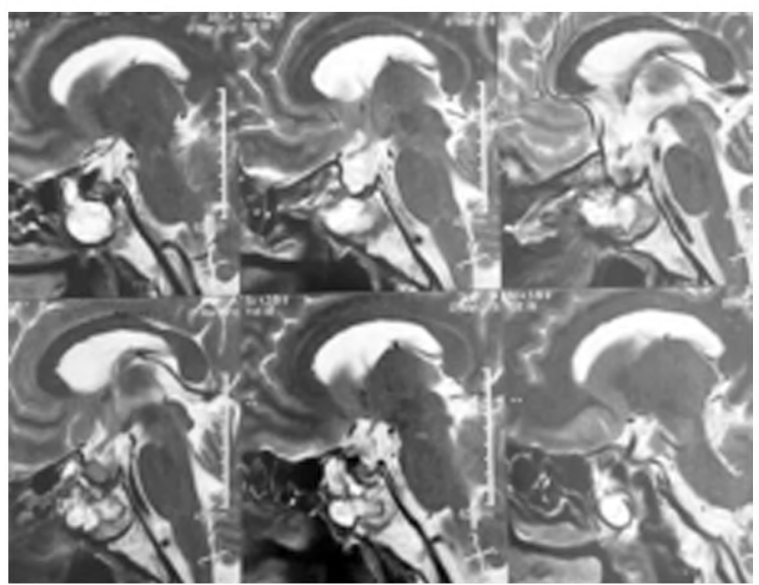

(E) with one week of CSF diversion via lumbar drainage. On long term follow-up one patient developed hypothyroidism and long term therapy with thyroxin was required. Recurrence was observed in $19 \%$ of cases during this period ( 5 cases).

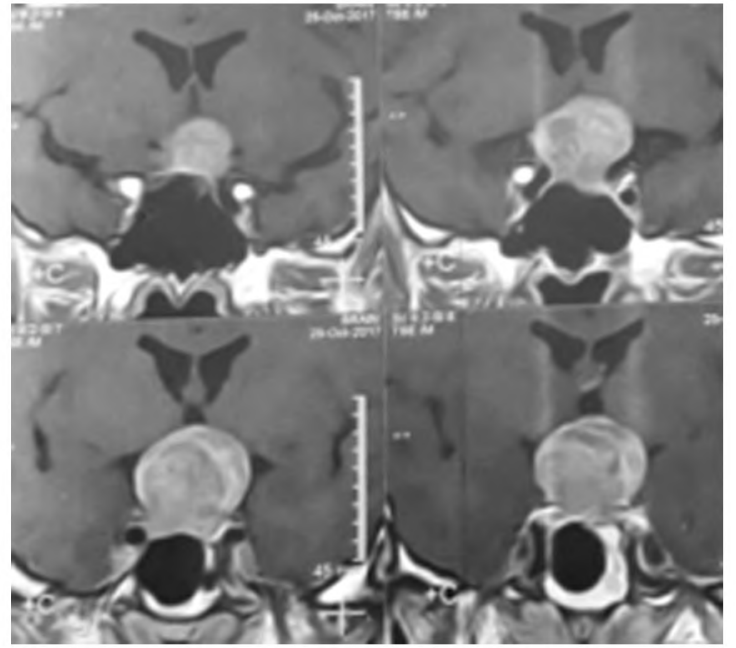

(B)

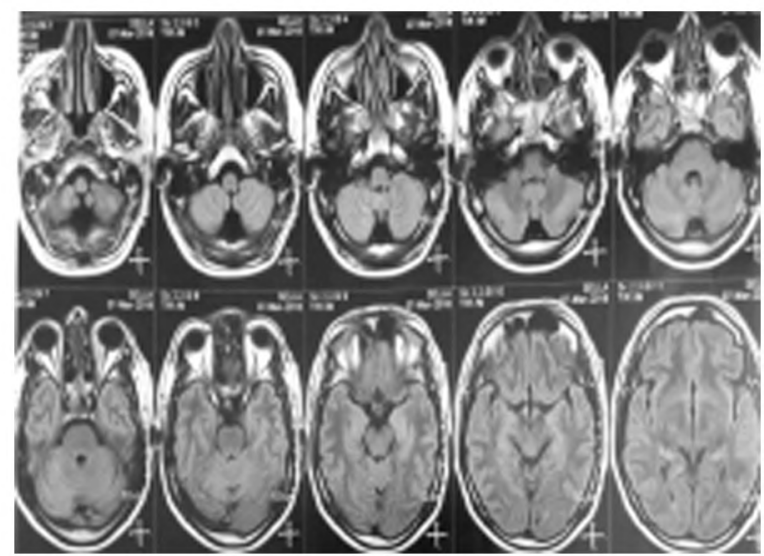

(D)

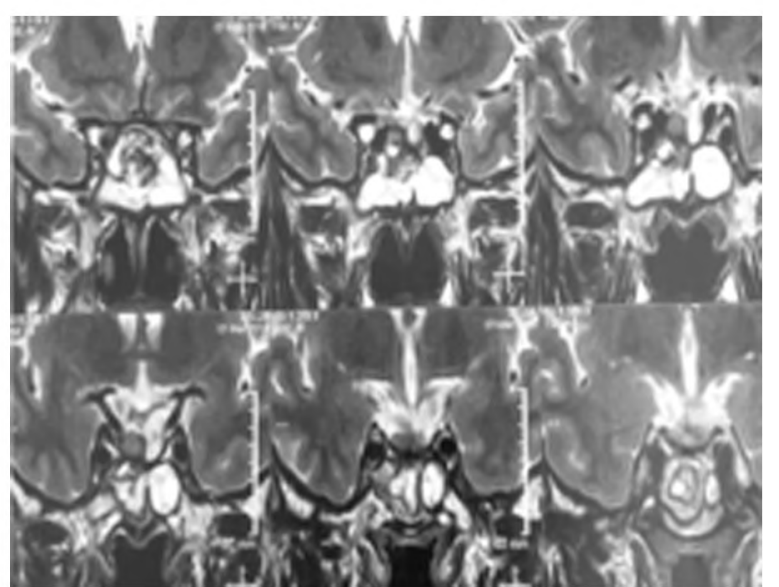

(F)

Fig. (1): (A, B, C) Pre-operative sagittal (T2), coronal and axial (with contrast) MRI images showing pituitary macroadenoma with suprasellar extension. (D, E, F) Post-operative axial (T1), sagittal (T2) and coronal (T2) of the same patient showing near total removal of the tumor. 
(A)

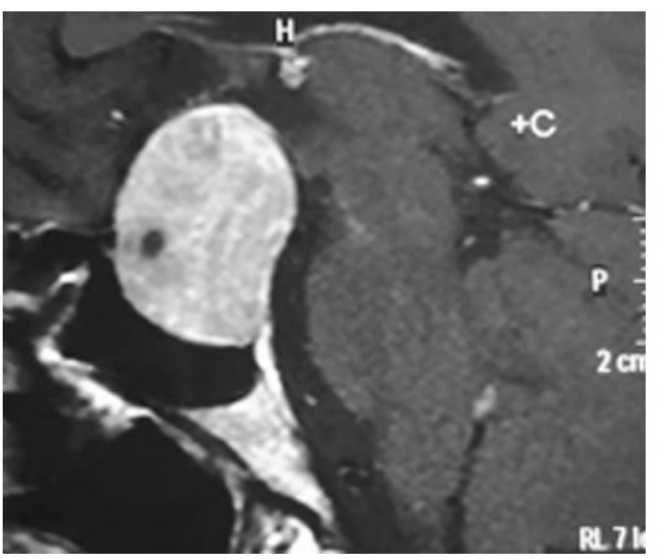

(C)

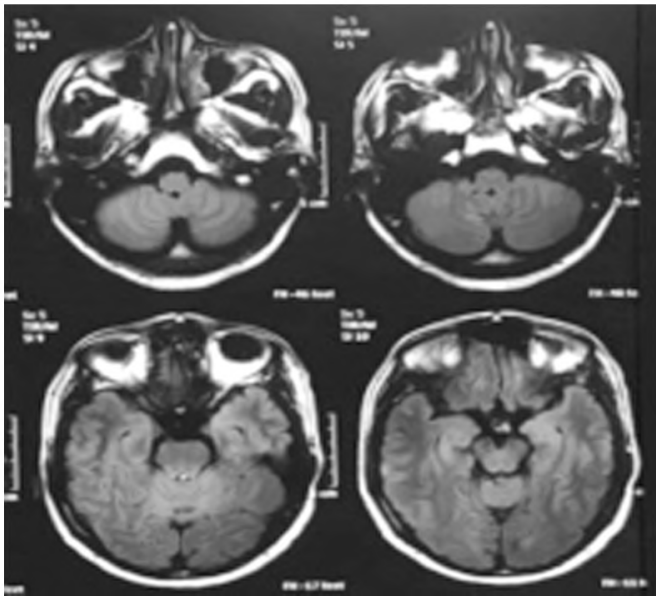

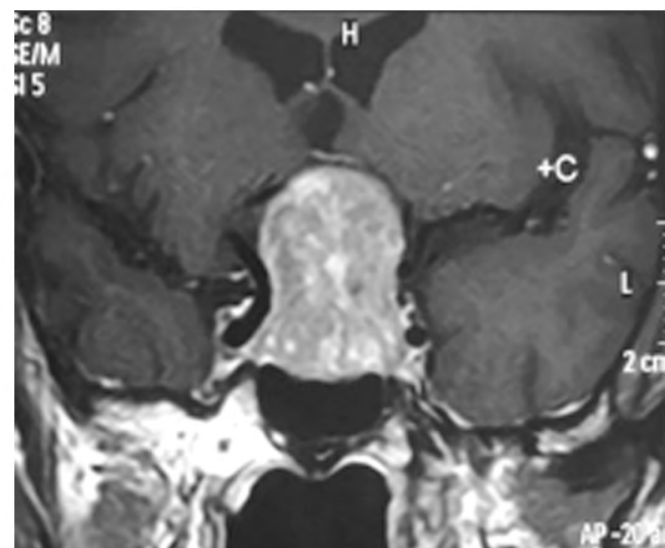

(B)

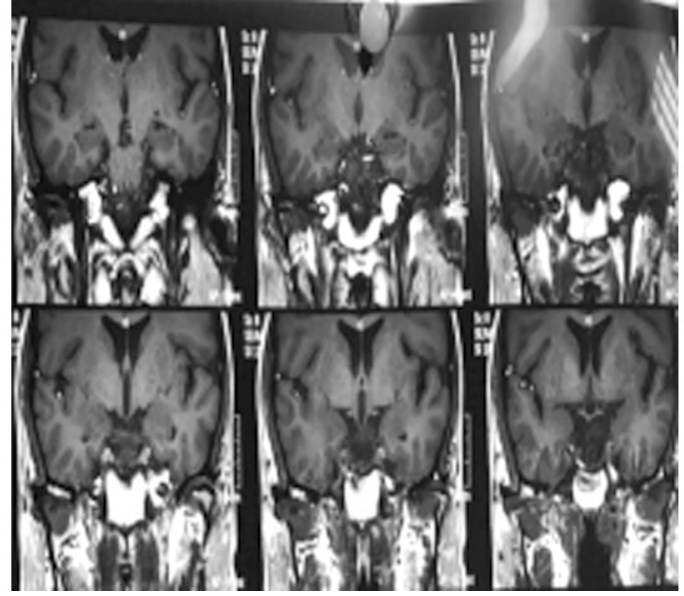

(D)

Fig. (2): (A, B) Pre-operative sagittal and coronal MRI images with contrast showing large sellar suprasellar mass with nonhomogenous enhancement. (C, D) Post-operative axial and coronal images of the same patient 8 months later with no obvious residual.

Table (1): Patient criteria.

\begin{tabular}{ll}
\hline Criteria & No. \\
\hline Sex: & $6(22 \%)$ \\
M & $21(78 \%)$ \\
F & 40 \\
Mean age & $3(11 \%)$ \\
Previous surgery & \\
Tumor size: & $8(29.5 \%)$ \\
$\quad<1$ CM & $19(70.5 \%)$ \\
$>1$ CM & $4(14.8)$ \\
CS invasion & $10(37 \%)$ \\
Suprasellar extension & $20(74 \%)$ \\
Prolactin level <200 & $6(22 \%)$ \\
Apoplexy &
\end{tabular}

Table (2): Predicators for endocrinological remission.

\begin{tabular}{lc}
\hline Adenoma characteristics & $p$-value \\
\hline GTR & .006 \\
Diameter $<1 \mathrm{~cm}$ & .0021 \\
No suprasellar extension & .0029 \\
No cavernous sinus invasion & .0039 \\
\hline
\end{tabular}

Table (3): Outcome in 27 cases of prolactinoma.

\begin{tabular}{ll}
\hline Criteria & No. \\
\hline GTR & $19(70 \%)$ \\
Endocrinologic remission & $19(70 \%)$ \\
GKS & $2(7.4 \%)$ \\
Mean time of FU & 24 months \\
Recurrence & $5(18.5 \%)$ \\
\hline
\end{tabular}

\section{Discussion}

Microsurgical transsphenoidal surgery for pituitary adenoma has been the standard treatment for decades in the neurosurgical community $[4,8]$.

Though only recently introduced to pituitary surgery, endoscopy is fast becoming the technique of choice at more and more neurosurgical centers. Combined with the endonasal approach, this technique undoubtedly allows a relatively painless post-operative course for patients $[\mathbf{1 - 3 , 5 , 7 , 9 , 1 2 , 1 6 ]}$ However, its superiority is still under debate in the absence of randomized studies and few series published to date. 
In this series of patients, we present endocrinological outcome following a purely endoscopic endonasal transsphenoidal surgery for functional pituitary adenomas.

Because the endoscopic technique constitutes the latest refinement of transsphenoidal surgery [17]. A comparison of our results with a standard microscopic transsphenoidal technique was performed.

In our series endocrinological cure was achieved for $70 \%$ of PRL-secreting adenomas. This is slightly heigher than the weighted average cure rate $(62 \%)$ derived from several microscopic series $[\mathbf{1 4 , 1 8}$.

In a study of endoscopic transsphenoidal surgery by Dehdashti and colleagues [6] at 2008 the same criteria for endocrinological cure for PRL-secreting adenomas were used as in the current series. However, adenoma characteristics are quite different. In the current series, $12 \%$ of PRL-secreting adenomas required an extended approach for appropriate access to suprasellar portions, whereas adenomas that required extended approaches were excluded by Dehdashti et al., Moreover, the rate of CS invasion was higher in the current series $(14.8 \%)$ compared with the aforementioned study (8\%). This may explain the higher biochemical cure rate $(88 \%)$ reported by Dehdashti and colleagues for their 25 prolactinomas.

In a study performed by Frank and colleagues [8] at 2006, the cure rate was $(75.7 \%)$ which is similar to that rate achieved in our series $(70 \%)$.

Endocrinological remission rates for PRLsecreting adenomas with invasion of CS in Frank and colleagues study [8] report a cure rate (36.5\%) that is lower than that in our study (50\%).

In a study performed by christoph et al., [4] at 2011 the cure rate was similar to that achieved in our series $(70.6 \%)$. Cavernous sinus invasion was present in (14\%) of cases which is similar to our series, suprasellar extension was present in $14 \%$ which is lower than that in our series $(37 \%)$.

\section{Conclusion:}

Better surgical outcome for endoscopic transsphenoidal surgery is associated with smaller tumor size, no suprasellar extension and absence of cavernous sinus invasion. So early tumor detection is very important.

\section{References}

1- BEAUREGARD C., TRUONG U., HARDY J. and SERRI O.: Long-term outcome and mortality after transsphenoidal adenomectomy for acromegaly. Clin. Endocrinol. (Oxf), 58: 86-91, 2003.

2- BOCHICCHIO D., LOSA M. and BUCHFELDER M.: Factors influencing the immediate and late outcome of Cushing's disease treated by transsphenoidal surgery: A retrospective study by the European Cushing's Disease Survey Group. J. Clin. Endocrinol. Metab., 80: 3114-20, 1995.

3- CAPPABIANCA P., CAVALlO L.M., COLAO A., Del BASSO De CARO M., ESPOSITO F., CIRILLO S., et al.: Endoscopic endonasal transsphenoidal approach: Outcome analysis of 100 consecutive procedures. Minim. Invasive Neurosurg., 45: 193-200, 2002.

4- CHRISTOPH P. HOFSTETTER, M.D., Ph.D., 1 BENJAMIN J., et al.: Endoscopic endonasal transsphenoidal surgery for functional pituitary adenomas. Neurosurg. Focus., 30 (4): E10, 2011.

5- COTTIER J.P., DESTRIEUX C., BRUNEREAU L., BERTRAND P., MOREAU L., JAN M., et al.: Cavernous sinus invasion by pituitary adenoma: MR imaging. Radiology, 215: 463-9, 2000.

6- DEHDASHTI A.R., GANNA A., KARABATSOU K. and GENTILI F.: Pure endoscopic endonasal approach for pituitary adenomas: Early surgical results in 200 patients and comparison with previous microsurgical series. Neurosurgery, 62: 1006-17, 2008.

7- De P., REES D.A., DAVIES N., JOHN R., NEAL J., MILLS R.G., et al.: Transsphenoidal surgery for acromegaly in wales: Results based on stringent criteria of remission. J. Clin. Endocrinol. Metab., 88: 3567-72, 2003.

8- FRANK G., PASQUINI E., FARNETI G., MAZZATENTA D., SCIARRETTA V., GRASSO V., et al.: The endoscopic versus the traditional approach in pituitary surgery. Neuroendocrinology, 83: 240-8, 2006.

9- FREDA P.U., WARDLAW S.L. and POST K.D.: Longterm endocrinological follow-up evaluation in 115 patients who underwent transsphenoidal surgery for acromegaly. J. Neurosurg., 89: 353-8, 1998.

10- HAE-DONG JHO, M.D., Ph.D., and RICARDO L. CARRAU, M.D.: Endoscopic endonasal transsphenoidal surgery: Experience with 50 patients. Neurosurg Focus: 1996.

11- HOFSTETTER C.P., MANNAA R.H., MUBITA L., ANAND V.K., KENNEDY J.W., DEHDASHTI A.R., et al.: Endoscopic endonasal transsphenoidal surgery for growth hormone-secreting pituitary adenomas. Neurosurg. Focus, 29 (4): E6, 2010.

12- LAUFER I., ANAND V.K. and SCHWARTZ T.H.: Endoscopic, endonasal extended transsphenoidal, transplanum transtuberculum approach for resection of suprasellar lesions. J. Neurosurg., 106: 400-6, 2007.

13- LUDECKE D.K. and ABE T.: Transsphenoidal microsurgery for newly diagnosed acromegaly: A personal view after more than 1,000 operations. Neuroendocrinology, 83: 230-9, 2006.

14- MAIRA G., ANILE C., De MARINIS L. and BARBARINO A.: Prolactinsecreting adenomas-surgical results. Can. J. Neurol. Sci., 17: 67-70, 1990. 
15- NOMIKOS P., BUCHFELDER M. and FAHLBUSCH R.: The outcome of surgery in 668 patients with acromegaly using current criteria of biochemical 'cure.' Eur. J. Endocrinol., 152: 379-87, 2005.

16- SCHABERG M.R., ANAND V.K., SCHWARTZ T.H. and COBB W.: Microscopic versus endoscopic transnasal pituitary surgery. Curr. Opin Otolaryngol. Head Neck Surg., 18: 8-14, 2010.

17- TABAEE A., ANAND V.K., BARRÓN Y., HILTZIK D.H., BROWN S.M., KACKER A., et al.: Endoscopic pituitary surgery: A systematic review and meta-analysis. Clinical article. J. Neurosurg., 111: 545-54, 2009.

18- TYRRELL J.B., LAMBORN K.R., HANNEGAN L.T., APPLEBURY C.B. and WILSON C.B.: Transsphenoidal microsurgical therapy of prolactinomas: Initial outcomes and long-term results. Neurosurgery, 44: 254-63, 1999.

19- YAP L.B., TURNER H.E., ADAMS C.B. and WASS J.A.: Undetectable post-operative cortisol does not always predict long-term remission in Cushing's disease: A single centre audit. Clin. Endocrinol (Oxf), 56: 25-31, 2002.

\title{
نواتج التدخل الجراحى لإزالة الآورام البرولاكتينية للغدة النخامية بالطريق الوتلدى
}

\author{
المقدمة: تعتبر الآقدام البرولاكتينية آكثر آنواع آوام الغدة النخامية شيوعاً حيث تمثل ما نسبته ثلاثقف بالمائة من آقدام الغدة النخامية.

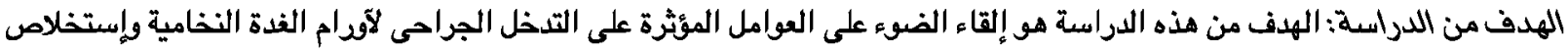

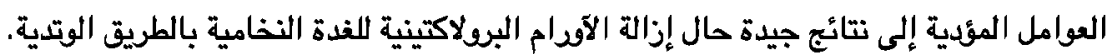 \\ تصميم الدراسة: دراسة وصفية إكلينيكية بآثر رجعى. \\ طريقة البحث: تم إجراء هذه الدراسة على TV مريض خضعوا إلى إجراء جراحة لإزالة الآوام البرولاكتينية للغدة النخامية بالطريق الوتدية

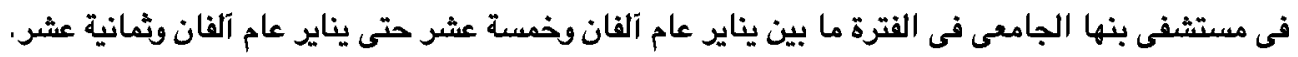

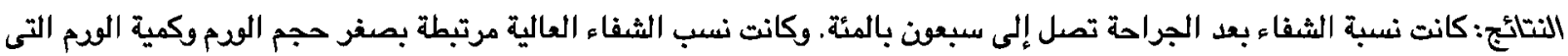

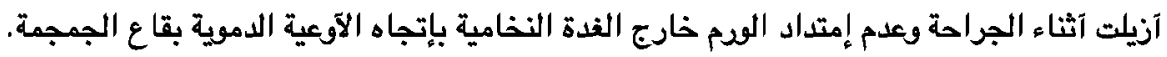

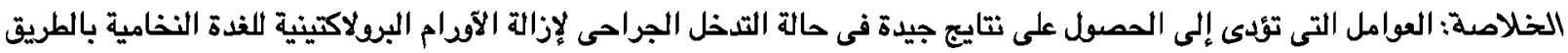

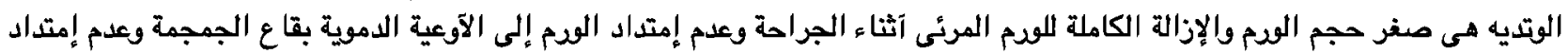

